\section{Identification of a differentially expressed thymidine kinase gene related to tapping panel dryness syndrome in the rubber tree (Hevea brasiliensis Muell. Arg.) by random amplified polymorphic DNA screening}

\author{
Perumal Venkatachalam, \\ Natesan Geetha, Padmanabhan Priya, ${ }^{2}$ \\ Arjunan Thulaseedharan \\ Advanced Centre for Biotechnology and \\ Molecular Biology, Rubber Research \\ Institute of India, Rubber Board, \\ Kottayam, India; \\ 'Department of Biotechnology, Periyar \\ University, Salem, TN, India; \\ ${ }^{2}$ Department of Plant and Microbial \\ Biology, University of California, \\ Berkeley, CA, USA
}

\section{Abstract}

Tapping panel dryness (TPD) syndrome is one of the latex yield affecting factors in the rubber tree (Hevea brasiliensis Mull. Arg.). Therefore, identification of a DNA marker will be highly useful for screening progenies in breeding programs. The major goal of this study was to detect genetic variations and/or identification of gene fragments among 37 Hevea clones by the random amplified polymorphic DNA "fingerprinting" technique. Different levels of DNA polymorphism were detected with various primers and a distinct polymorphic band (2.0 kb) was obtained with OPA-17 primer. It was cloned into a plasmid vector for further sequence characterization and the nucleotide sequence shows homology with a novel putative plant thymidine kinase (TK) gene, designated as HbTK (Hevea brasiliensis thymidine kinase; GenBank accession number AY130829). The protein HbTK has $67 \%, 65 \%, 64 \%$, and $63 \%$ similarity to TK genes of Medicago, Oryza, Arabidopsis, and Lycopersicon, respectively, and it was highly conserved in all species analyzed. The predicted amino acid sequence contained conserved domains of TK proteins in the C-terminal half. Southern blot analysis indicated that $H b T K$ is one of the members of a small gene family. Northern blot results revealed that the expression of the $H b T K$ gene was up-regulated in mature bark tissues of the healthy tree while it was down-regulated in the TPD-affected one. These results suggest that this gene may play important roles in maintaining active nucleotide metabolism during cell division at the tapped site of bark tissues in the healthy tree under stress (tapping) conditions for normal latex biosynthesis.

\section{Introduction}

Natural rubber (cis-1,4-polyisoprene) is produced in latex at the expense of high energy cost, and is considered as a secondary metabolite with no known function in plant cells. Latex is the cytoplasmic fluid of laticiferous cells that contain the usual organelles of plant cells such as nucleus, mitochondria, vacuoles, ribosomes, Golgi apparatus, and endoplasmic reticulum. ${ }^{1}$ Rubber is an important raw material for many industrial uses requiring elasticity, flexibility, and resilience. Although over 2000 species of higher plants are recognized for producing latex, ${ }^{2}$ only the rubber tree (Hevea brasiliensis Muell. Arg. $2 \mathrm{n}=36$ ) has been established as a key commercial rubber source owing to its good yield of rubber and the excellent physical properties of the rubber products. ${ }^{2}$ Apart from its latex, the rubber tree has also been harnessed for its wood for making furniture and the seeds for para-rubber seed oil used for manufacturing soap, paint, varnishes, fertilizer, and animal feeds. Exploitation of these other components of the rubber tree added further value to the planting of rubber trees. The rubber is harvested by tapping into the pipe-like network of latex-containing laticifers that run beneath the bark; a labor-intensive procedure. The expense of tapping and tropical growth requirements of the tree makes Hevea brasiliensis unsuitable in the United States and other cold countries.

The rubber tree is cultivated on a large commercial scale in several tropical countries including India, amounting to 9.5 million hectares, producing about 8.7 million tons of dry rubber each year worldwide. ${ }^{3}$ The diminishing acreage of rubber plantations and various stresses to Hevea coupled with an increasing demand have triggered research interests in the study of the development of molecular markers for biotic and abiotic stresses. ${ }^{4}$ In the rubber tree, tapping panel dryness (TPD) is one of the important syndromes that greatly affect the latex yield. Once TPD occurs, the tapping panel region of the rubber tree is partly or entirely dried and the latex biosynthesis is decreased significantly or stops completely. The incidence of TPD occurs in $20-50 \%$ of the trees in almost every rubber planting country. It is estimated that the loss of dry rubber owing to TPD is $15-20 \%$ of the annual rubber production. Despite the number of studies attempted so far, the original cause for the onset of TPD still remains poorly understood. As different clones of rubber tree showed varying degrees
Correspondence: Perumal Venkatachalam, Department of Biotechnology, Periyar University, Salem-636 011, TN, India.

E-mail: pvenkat67@yahoo.com or pvenkat67@ gmail.com

Key words: cloning, Hevea brasiliensis, random amplified polymorphic DNA fingerprints, rubber tree, tapping panel dryness, thymidine kinase gene.

Acknowledgements: the authors wish to thank Drs James Jacob (Director) and NM Mathew (Former Director) for their constant encouragement.

Received for publication: 7 August 2009.

Revision received: 10 March 2010

Accepted for publication: 10 March 2010.

This work is licensed under a Creative Commons Attribution 3.0 License (by-nc 3.0).

(C) Copyright P. Venkatachalam et al., 2010 Licensee PAGEPress, Italy

International Journal of Plant Biology 2010; 1:e7 doi:10.4081/pb.2010.e7

of susceptibility to TPD in field tests, the gene associated with TPD syndrome is yet to be identified. $^{5}$

With the advent of recombinant DNA technology, different types of molecular markers became available to breeders, geneticists, and germplasm specialists. Molecular markers serve as useful aids in understanding the genetics of the rubber tree, and already they have been applied to investigate the genetic variations between clones and tagging genes in the recent past. ${ }^{4}$ A range of molecular marker systems is available to detect DNA polymorphism. Random amplified polymorphic DNA (RAPD) "fingerprinting” yields patterns of DNA fragments that reflect differences in template sequence ${ }^{6}$ which is straightforward and reproducible. ${ }^{7}$ In addition to their value in mapping, map-based cloning, MAS, and gene "tagging" studies, RAPDs have been deployed in various plant species including Hevea for detection of genetic variations. ${ }^{4,7-10}$ Presence or absence of DNA bands in the gel may be used as RAPD markers to study inter- and intra-specific genetic variation ${ }^{11}$ for the identification of specific genes ${ }^{4,12,13}$ and to study the pattern of gene expression. ${ }^{14}$ Although few protein markers associated with TPD have been reported, ${ }^{15-17}$ no DNA marker is available for identification and/or early detection of TPD syndrome in this important commercial tree crop at present.

It has been reported that TPD is genetically controlled in Hevea ${ }^{5}$ and there is still the possibility of developing DNA markers for this syndrome. The main focus of our present study is to detect genetic variations within 37 cultivated rubber clones using RAPD fingerprint- 
ing. This paper reports identification, cloning, and sequence characterization of a polymorphic band, and its expression pattern is correlated between healthy and TPD-affected rubber trees to consider it as a potential molecular marker for the detection of the TPD syndrome.

\section{Materials and Methods}

\section{Plant material}

In total, 37 clones originating from six countries were used in this investigation. These clones had genetic variation in several desirable traits including high yield potential, tolerant and/or susceptible to leaf diseases, TPD, wind damage, drought, and cold (Table 1). Plants selected for this experiment were cultivated in the nursery as well as experimental field at the Rubber Research Institute of India (RRII). Fully expanded and disease-free leaves on the main stem were utilized for genomic DNA extraction.

\section{Genomic DNA extraction}

Total genomic DNA was isolated from young leaves according to the procedures described by Venkatachalam et al. ${ }^{9}$ Briefly, fresh leaf tissue $(1 \mathrm{~g})$ was ground to a fine powder under liquid nitrogen in a mortar-and-pestle and homogenized in DNA isolation buffer [2\% cetyltriethylammonium bromide (CTAB); 1.4 M NaCl, 20 mM EDTA (pH 8.0), 100 mM Tris$\mathrm{HCl}(\mathrm{pH} 8.0), 1 \%$ polyvinyl polypyrolidone (PVPP), 1\% 2-mercaptoethanol]. The homogenate was kept in a water bath at $65^{\circ} \mathrm{C}$ for 30 min and the tubes were agitated frequently. The extracts were centrifuged for $15 \mathrm{~min}$ (8000 rpm) and the supernatant was transferred to fresh centrifuge tubes and re-extracted with an equal volume of phenol:chloroform:isoamylalcohol (25:24:1) and spun at 10,000 rpm for $10 \mathrm{~min}$. The top aqueous phase was transferred carefully to new tubes and incubated at $37^{\circ} \mathrm{C}$ for $1 \mathrm{~h}$ after the addition of $10 \mu \mathrm{L}$ of RNase A $(10 \mathrm{mg} / \mathrm{mL})$. The samples were extracted with an equal volume of chloroform (100\%) and spun at 10,000 rpm for $5 \mathrm{~min}$ and re-extracted until a clear aqueous phase was obtained. The DNA was precipitated with 0.6 volume of ice-cold isopropanol (100\%). After 15 min of centrifugation at $10,000 \mathrm{rpm}$, the DNA pellet was washed with $70 \%$ (v/v) ethanol, air dried, and dissolved in about $300 \mu \mathrm{L}$ of TE buffer (10 mM Tris-HCl, pH 8.0; 1 mM EDTA, $\mathrm{pH}$ 8.0). DNA was quantified by comparison with ethidium bromide-stained standard concentrations in $0.8 \%(\mathrm{w} / \mathrm{v})$ agarose gels and stored at $-20^{\circ} \mathrm{C}$ until used for polymerase chain reaction (PCR) amplification.

Table 1. Morphological characteristics of 37 cultivated rubber tree (Hevea brasiliensis) clones used in this study.

\begin{tabular}{|c|c|c|c|c|}
\hline №. & Clones & Major characteristics & Parentage & Origin \\
\hline 1. & RRII105 & High yield, ALF tolerance, TPD severe & Tjirl x Gll & India \\
\hline 2. & RRIM600 & High yield, ALF susceptible, TPD susceptible & Tjirl x PB86 & Malaysia \\
\hline 3. & PB217 & Average yield, TPD mild, PM severe, ALF low & $\mathrm{PB} 5 / 51 \times \mathrm{PB} 6 / 9$ & Malaysia \\
\hline 4. & PB235 & High yield, TPD mild, PM severe, ALF medium & PB5/51 x PB S/78 & Malaysia \\
\hline 5. & PB255 & High yield, ALF susceptible, PM tolerance, TPD medium & $\mathrm{PB} 5 / 51 \times \mathrm{PB} 32 / 36$ & Malaysia \\
\hline 6. & PB260 & High yield, ALF medium, PM severe, TPD medium & PB5/51 x PB49 & Malaysia \\
\hline 7. & PB280 & High yield, ALF medium, PM severe, TPD mild & PBIG seedlings & Malaysia \\
\hline 8. & PB310 & PM susceptible, TPD medium & RRIM600 x PB5/51 & Malaysia \\
\hline 9. & PB311 & High yield, PM medium, TPD mild & RRIM600 x PB235 & Malaysia \\
\hline 10. & PB312 & Average yield, TPD mild & RRIM600 x PB235 & Malaysia \\
\hline 11. & PB314 & ALF tolerance, TPD mild & RRIM600 x PB235 & Malaysia \\
\hline 12. & SCATC93-114 & Cold tolerance & TR31-45xHaiken3-11 & China \\
\hline 13. & Haikenl & Wind tolerance, TPD mild & Primary clone & China \\
\hline 14. & KRS25 & ALF average, TPD medium & Primary clone & Thailand \\
\hline 15. & KRS128 & ALF average & RRIM501 x PB5/63 & Thailand \\
\hline 16. & KRS163 & ALF tolerance & RRIM501 x PB5/65 & Thailand \\
\hline 17. & RRII201 & High yield, TPD tolerance, ALF susceptible & Tjirl x PB25 & India \\
\hline 18. & RRII202 & High yield, TPD susceptible & PB 86 x Mil3/2 & India \\
\hline 19. & RRII203 & High yield, disease tolerance, timber clone & PB86 x Mil3/2 & India \\
\hline 20. & RRII204 & High yield, TPD mild, disease susceptible & PB86 x Mil3/2 & India \\
\hline 21. & RRII205 & Average yield, TPD tolerance & PB86 x BD10 & India \\
\hline 22. & RRII206 & High yield, TPD tolerance & Mil3/2 x AVROS255 & India \\
\hline 23. & RRII207 & Average yield, disease tolerance, TPD susceptible & Mil3/2 x AVROS255 & India \\
\hline 24. & RRII208 & Moderate yield, cold tolerance, wind damage low, TPD medium & Mil3/2 x AVROS255 & India \\
\hline 25. & RRII209 & High yield, wind damage high, disease susceptible, TPD mild & Mil3/2 x BD10 & India \\
\hline 26. & PR107 & Average yield, ALF susceptible, PM, wind tolerance & Primary clone & Indonesia \\
\hline 27. & PB5/63 & Wind damage, Gloeosporium susceptible & PB56 x PB24 & Malaysia \\
\hline 28. & Mil3/2 & Low yield, disease tolerance & Primary clone & Sri Lanka \\
\hline 29. & $\mathrm{BD} 10$ & TPD medium, PM tolerance & Primary clone & Indonesia \\
\hline 30. & AVROS255 & Low yield, ALF and PM susceptible & Primary clone & Indonesia \\
\hline 31. & Tjirl & ALF and PM susceptible, TPD medium & Primary clone & Indonesia \\
\hline 32. & $\mathrm{~PB} 6 / 9$ & High yield, TPD medium & PB24 x PB28 & Malaysia \\
\hline 33. & Gll & ALF tolerance, TPD susceptible, drought tolerance & Primary clone & Malaysia \\
\hline 34. & PB86 & ALF susceptible, PM tolerance, TPD mild & Primary clone & Malaysia \\
\hline 35. & RRIM501 & High yield, TPD tolerant, Pink and wind damage susceptible & PilA44 x LunN & Malaysia \\
\hline 36. & PB5/51 & ALF tolerance, PM susceptible, TPD mild & PB86 x PB24 & Malaysia \\
\hline 37. & PB25 & TPD \& wind damage susceptible & Primary clone & Malaysia \\
\hline
\end{tabular}

ALF, abnormal leaf fall; PM, powdery mildew; TPD, tapping panel dryness.

\section{Random amplified polymorphic DNA fingerprinting and gel elec- trophoresis}

RAPD reactions were carried out with different oligonucleotide primers (Operon Technologies Inc., USA). PCR reaction mixtures $(20 \mu \mathrm{L})$ consisted of $10 \mathrm{mM}$ Tris-HC1, 50 mM KCl, $1.5 \mathrm{mM}$ each dNTP (dATP, dCTP, dGTP, dTTP), $250 \mathrm{nM}$ primer, $1.5 \mathrm{mM} \mathrm{MgCl}, 10 \mathrm{ng}$ DNA template, and 0.5 units (U) Taq DNA polymerase, overlaid with $50 \mu \mathrm{L}$ of mineral oil to prevent evaporation. RAPD reactions were performed in a thermal cycler (Perkin Elmer 480) with the following PCR conditions: $94^{\circ} \mathrm{C}$ for 4 min followed by 39 cycles of $94^{\circ} \mathrm{C}$ for $1 \mathrm{~min}$, $37^{\circ} \mathrm{C}$ for $1.30 \mathrm{~min}, 72^{\circ} \mathrm{C}$ for $2 \mathrm{~min}$, and a final extension at $72^{\circ} \mathrm{C}$ for $10 \mathrm{~min}$. Reaction products were separated by electrophoresis in $1.5 \%$ (w/v) agarose gels using a Tris-Borate-EDTA (TBE) buffer system. ${ }^{18}$ Permanent records were obtained by photographing ethidium bromide-stained gels under UV light. Band sizes were determined by comparison with the DNA ladder ( $\lambda$-DNA double digest with HindIII/ EcoRI, Bangalore Geni., Bangalore) in each gel. Reactions were kept at $4^{\circ} \mathrm{C}$ until analyzed 
and four repeat reactions were carried out to ensure the fidelity and reproducibility of results. For each clone, the presence and/or absence of fragments was recorded as 1 or 0 , respectively. The selection of polymorphic bands for inclusion in the data set was based on band reliability, clarity, signal strength, and resolution. Faint RAPD bands were not considered in this analysis.

\section{Random amplified polymorphic DNA data analysis}

All bands were scored as either present or absent. Polymorphisms at most of the loci were confirmed by repeating tests on all the relevant genotypes. A conservative approach to scoring of the amplified fragments was adopted and only consensus bands were included for the final analysis. Individual amplified bands were indicated by the primer used, its size in bp. Data were scored for computer analysis on the basis of the presence or absence of the amplified product of a given length. We retained only the major fragments that were unambiguously present. If a product was present in a genotype it was designated " 1 "; if absent it was designated " 0 ". Pair-wise comparisons of genotypes, based on the presence or absence of unique and shared polymorphic products were used to generate Jaccord's similarity coefficients. The matrix of similarities was used to construct a dendrogram according to the UPGMA (unweighted pair-group method with arithmetical average) using a computer program.

\section{Cloning of a polymorphic band and nucleotide sequence analysis}

One of the polymorphic DNA fragments amplified from TPD- tolerant clone PB235 was excised from low melting agarose gel and the DNA was purified using the standard protocol. $^{18}$ The DNA fragments were ligated into the pGEM-T easy vector (Promega Inc., USA) and cloned into a competent Escherichia coli (DH5 $\alpha$ ) strain. The selection of transformed clones was performed by PCR analysis using white colonies directly as templates. Positive colonies were grown overnight in $10 \mathrm{~mL}$ of Luria Bertani (LB) medium containing 50 $\mu \mathrm{g} / \mathrm{mL}$ ampicillin. To confirm the presence of the cloned DNA fragment, purification of plasmid DNA was carried out from five independent transformed clones using a mini preparation. The DNA insert size was checked by double digestion with Not I enzyme followed by separation in a $1.5 \%(\mathrm{w} / \mathrm{v})$ agarose gel. The complete sequence of cloned fragment was obtained using an Automated DNA sequencer (Indian Institute of Science, Bangalore, India). The nucleotide sequences were analyzed for homologies in the GenBank data base using the BLAST programme at NCBI (http://www.ncbi.nlm.hih.gov). ${ }^{19}$ Alignment of amino acid sequences and phylogenetic tree analysis were performed using the ClustalW program..$^{20}$

\section{Genomic Southern hybridization analysis}

Total genomic DNA extracted from the PB235 clone was digested with different restriction enzymes (HindIII, EcoRI, EcoRV, $B a m H I$, and $X b a \mathrm{I}$ ) and digested DNA fragments were electrophoresed on 1.0\% (w/v) agarose gel in TBE buffer ( $0.045 \mathrm{M}$ Tris-borate and $0.001 \mathrm{M}$ EDTA) at $50 \mathrm{~V}$ for $6 \mathrm{~h}$. After depurination in $0.25 \mathrm{M} \mathrm{HCl}$ for $10 \mathrm{~min}$, denaturation of the DNA in the gels was carried out in a buffer containing $1.5 \mathrm{M} \mathrm{NaCl}$ and $0.5 \mathrm{M} \mathrm{NaOH}$ for 30 min, followed by neutralization in $1.5 \mathrm{M} \mathrm{NaCl}$ and 1.0 M Tris-HCl (pH 7.4) buffer for $30 \mathrm{~min}$. The DNA was then transferred onto a nylon membrane (Hybond $\mathrm{N}^{+}$, AmershamPharmacia, UK) in $10 \times \mathrm{SSC}(1 \times \mathrm{SSC}$ is $0.15 \mathrm{M}$ $\mathrm{NaCl}, 0.015 \mathrm{M}$ trisodium citrate) for $18 \mathrm{~h}^{18}$ After DNA transfer, the nylon membranes were rinsed in $2 \times \mathrm{SSC}$ buffer, UV-crosslinked, and stored at $4^{\circ} \mathrm{C}$ until use. The TK gene fragment was amplified from the plasmid that contained the RAPD fragment by PCR, and the purified DNA fragment (25 ng) was used for labeling. The radioactive probe was synthesized with [ $\left.\alpha{ }^{32} \mathrm{P}\right]-\mathrm{dCTP}$ (BARC, Trombay, Mumbai, India, $4000 \mathrm{Ci} / \mathrm{mmol}$ ) using the random primer labeling kit (Amersham-Pharmacia, UK) according to the manufacturer's protocol, followed by purification with Sephadex G-50 spin columns. The nylon membranes with DNA were placed in hybridization bottles and prehybridized for $2 \mathrm{~h}$ (hybridization buffer is $6 \times \mathrm{SSC}$, $5 \times$ Denhardt's, $0.5 \%$ SDS, $0.2 \mathrm{mg} / \mathrm{mL}$ salmon sperm DNA) at $65^{\circ} \mathrm{C}$. Then the denatured [ $\alpha$ $\left.{ }^{32} \mathrm{P}\right]$-dCTP TK gene probe was added into the prehybridization buffer and hybridization was continuously performed at $65^{\circ} \mathrm{C}$ for $20 \mathrm{~h}$ in a rotary hybridization oven (AmershamPharmacia, UK). After completion of hybridization, membranes were washed at low stringency at room temperature twice in $2 \times \mathrm{SSC}+$ $0.1 \%$ SDS for 5 min and $1 \times \mathrm{SSC}+0.1 \%$ SDS for $15 \mathrm{~min}$ and high stringency at $65^{\circ} \mathrm{C}$, once in $0.5 \times \mathrm{SSC}+0.1 \%$ SDS for $15 \mathrm{~min}$ and $0.1 \times \mathrm{SSC}$ $+0.1 \%$ SDS for $15 \mathrm{~min}$, followed by radioactive signal generation. Then the labeled blots were exposed to X-ray film (X-Omat, Kodak) with intensifying screens at $-80^{\circ} \mathrm{C}$ for $1-3$ days.

\section{Total RNA isolation and Northern blot analysis}

For Northern blot analysis, high latex yielding rubber clones PB235 (TPD tolerant) and RRII 105 (TPD susceptible) were selected and trees regularly tapped [tapping is a controlled shaving of a thin bark section (about $2 \mathrm{~mm}$ ) with a special kind of tapping knife under $\mathrm{d} / 2$ (trees are being wounded alternate days for latex collection) tapping system for latex collection for the past 13 years]. Some of these trees developed TPD syndrome, but tapping them was continued along with the healthy trees to maintain uniform conditions before sample collection. Bark tissues and latex (laticifer cell cytoplasm) samples were collected from five healthy and TPD- affected trees and pooled before total RNA extraction. ${ }^{21}$ The mRNA quantity and quality were determined spectrophotometrically at 260 and $280 \mathrm{nM}$.

Aliquots $(15 \mu \mathrm{g})$ of total RNAs from samples representing healthy and TPD trees were denatured at $65^{\circ} \mathrm{C}$ for 15 min in a buffer containing formamide, formaldehyde, $10 \times$ MOPS buffer (0.2M MOPS, $50 \mathrm{mM}$ sodium acetate, 10 mM EDTA, pH 7.0) and ethidium bromide (10 $\mathrm{mg} / \mathrm{mL}$ ). RNA samples were fractionated in a formaldehyde-agarose gel $(1.2 \% \mathrm{w} / \mathrm{v})$ at $65 \mathrm{~V}$ for $3 \mathrm{~h}$ in $1 \times$ MOPS buffer. RNA was then transferred onto a Hybond $\mathrm{N}+$ nylon membrane (Amersham) by capillary blotting overnight using $10 \times$ SSC. RNA was crosslinked in a UVcrosslinker. The membrane was prehybridized for $2 \mathrm{~h}$ in $10 \mathrm{~mL}$ of a prehybridization buffer (50\% formamide, $6 \times$ SSPE, $5 \times$ Denhardt's, $0.5 \%$ SDS, $0.2 \mathrm{mg} / \mathrm{mL}$ salmon sperm DNA) in a hybridization incubator (Amersham) with constant rotation at $42^{\circ} \mathrm{C}$. The hybridization probe was prepared as described previously. Then the denatured $\left[\alpha-{ }^{32} \mathrm{P}\right]$-dCTP TK gene probe was added and the membrane was hybridized overnight in the same buffer at $42^{\circ} \mathrm{C}$. The membrane was washed twice (10 min each) in $2 \times \mathrm{SSC}+0.1 \% \mathrm{SDS}$ at room temperature. After this, high stringency washing was carried out for 10 min in $0.1 \times \mathrm{SSC}+0.1 \% \mathrm{SDS}$ at $42^{\circ} \mathrm{C}$ and then exposed to an X-ray film for 1-3 $\mathrm{d}$ with an intensifying screen for signal detection.

\section{Results}

Enhanced latex (rubber) production has been achieved substantially by releasing new high yielding rubber clones during the last two decades (Figure 1A). However, TPD is considered as a serious malady affecting rubber biosynthesis in high-yielding rubber clones worldwide (Figure 1B, C, D). The major goal of this experiment was to develop a nondestructive, early DNA diagnostic system to implement marker-assisted selection (MAS) in breeding programs. Therefore, we made an attempt to develop DNA markers using RAPD fingerprinting. DNAs extracted from 37 Hevea clones were used for RAPD reactions. A total of 140 arbitrary sequence decamers were tested as primers for RAPD fingerprinting. Of these, 16 primers gave reproducible polymorphic profiles, while one primer produced a monomorphic banding pattern within the 37 clones analyzed. PCR products amplified by these primers varied in size from $300 \mathrm{bp}$ to $3500 \mathrm{bp}$. 
Reproducibility of the RAPD fingerprinting pattern was tested by repeating each preparation at least thrice without alteration in the method. Different primers produced a RAPD profile of variable intensity from each clone examined. Although several polymorphic bands were detected among 37 clones, most of them were found to be faint and not considered as potential markers. Among the primers examined, 0PA-17 primer amplified a bright and distinct uncommon band of approximately $2.0 \mathrm{~kb}$ with some clones, along with several common bands. The RAPD profile observed with 0 PA-17 primer ( $5^{\prime}$-GACCGCTTGT-3') is depicted in Figure 2. This polymorphic band was amplified from 21 clones and it was absent or poorly amplified (not scorable) in the remaining 16 clones used for RAPD analysis.

RAPD profiles were used to construct dendrograms and clones originating from different countries were clearly distinguished (Figure 3). The rubber clones are classified into seven major groups based on DNA markers. The phenogram showed that RRII105 (India) and RRIM600 (Malaysia) clustered together and these were susceptible to the TPD syndrome. Further, it is interesting to note that most of the TPD-susceptible clones formed together in the same clusters. Although the rubber clones originated from different countries (India, Malaysia, and Indonesia), TPDtolerant clones have been put in the same cluster with three major groups according to their origin. The two clusters formed by the Indian clones were distinct, with one group (RRII201, and RRII204, RRII205, RRII206, RRII208, and RRII209) clustering with Malaysian clones. The clones PB217, PB260, PB312, and PB314 were grouped together. In our present study, it is interesting to note that most of the primary clones, such as TJIR1, PB86, and BD10, are closely clustered. In most cases, clones with a common pedigree, such as PB311, PB312, PB314, PB217, PB255, PB260, RRII204, RRII209, were observed to cluster together.

To characterize this polymorphic band further, it was cloned successfully into the pGEM$T$ vector and the presence of the cloned RAPD fragment in the recombinant plasmid was confirmed by both PCR and restriction digestion analysis. The cloned DNA fragment was sequenced subsequently (the nucleotide sequence is illustrated in Figure 4) and also deposited in the NCBI GenBank database (Accession no. AY130829). The first ten nucleotides from either side of the sequences obtained showed exact homology with the corresponding RAPD primer used for PCR amplification. The cloned RAPD marker consists of 2017 bp. BLAST analysis of the sequenced product identified it as the nuclear encoded novel putative plant thymidine kinase (TK) gene (378 bp; $126 \mathrm{aa}$ ) in which one intron (202 bp) was also detected. Attempts to isolate the
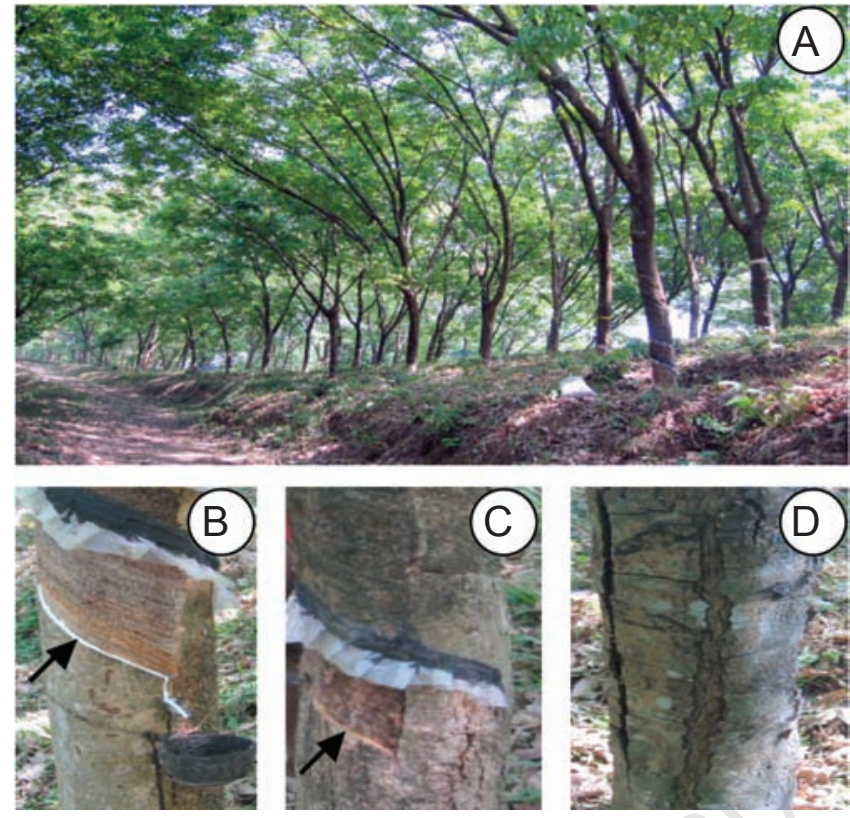

Figure 1. (A) Hevea rubber trees are growing at an experimental field of the Rubber Research Institute of India. (B) A healthy rubber tree with normal latex flow into the cup (arrow). (C) A TPDaffected tree with no latex flow at the tapped site (arrow). (D) Advanced stages of TPD in the affected tree, showing cracked bark tissue that is flaking.

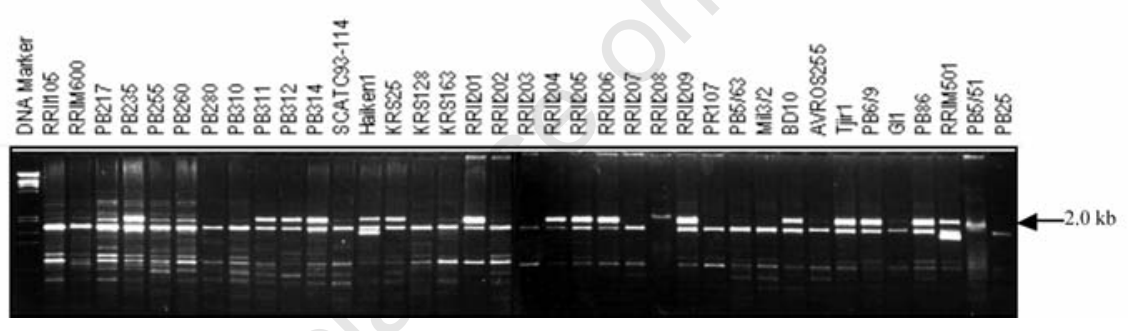

Figure 2. Genomic DNA from 37 Hevea clones was amplified using OPA-17 primer. The arrow indicates positions of the polymorphic band at $2.0 \mathrm{~kb}$.

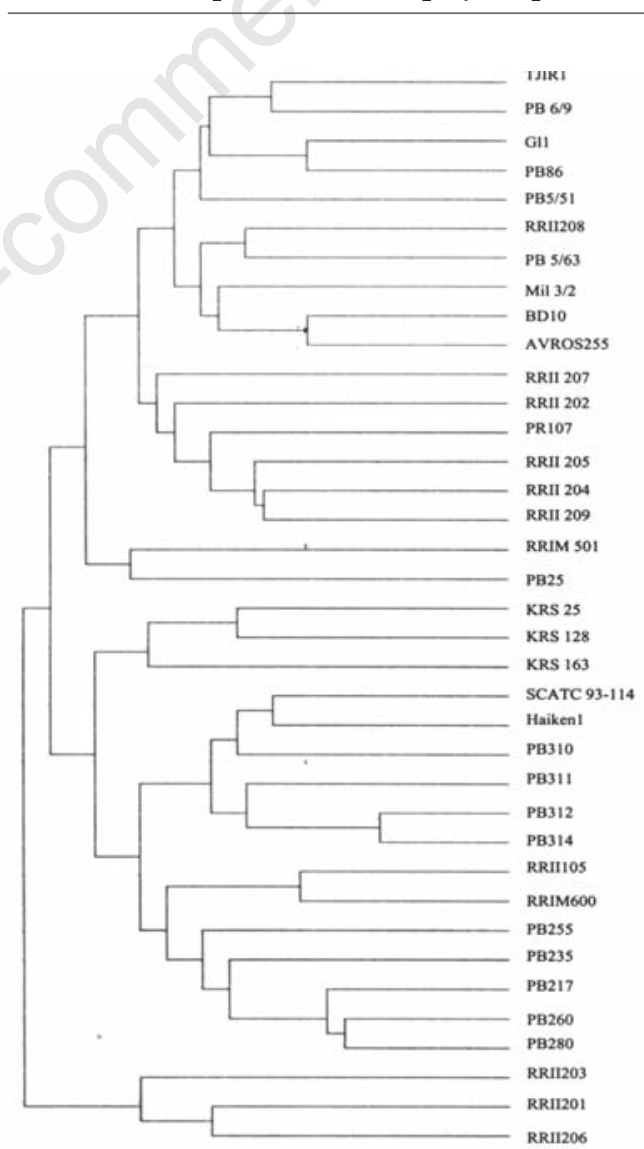

Figure 3. The dendrogram generated by UPGMA analysis. The bar on the top represents the dissimilarity index based on Jaccord's coefficients. 
full-length cDNA by RT-PCR were unsuccessful. The multiple amino acid alignment is presented in Figure 5A. According to pair-wise BLAST analysis, the truncated HbTK gene shares 67\% homology with the Medicago TK gene (ABE88233), 65\% amino acid sequence identity with the Oryza TK gene (AF066050, 212 aa), 63\% similarity with the Lycopersicon TK1 gene (AF514775, $234 \mathrm{aa}$ ), and 64\% homology with the Arabidopsis TK gene (AF370344, 238aa). All the TKs used for the analysis have a TK-conserved domain in the C-terminal half that is involved in nucleotide transport and metabolism. SignalP prediction suggests the presence of a signal peptide near the $\mathrm{N}$ terminus of the HbTK protein (MCILF FLVSV ILTHD EYMVQ LDVIG IDEAQ) and it is predicted to be located in the cytosol. The phylogenetic relationship of TK proteins from various taxa is shown in Figure 5B. The TK of Hevea formed a cluster with the TK of Medicago and branched with Oryza and Lycopersicon homologues.

To investigate the copy number and distribution of the TK gene in the Hevea genome, Southern hybridizations were performed on genomic DNA using the HbTK gene as hybridization probe (Figure 6A). On the blot, a major signal was detected in the DNA digests with EcoRI, EcoRV, HindIII, and XbaI, together with few weak signals (Figure 6B). This result suggests that $H b T K$ is encoded by a small gene family in Hevea. Further, we compared the expression pattern of the $H b T K$ gene in mature bark tissues and latex cells between healthy and TPD-affected trees using Northern blot analysis (Figure 6C, D). As expected, mRNA transcript accumulation was down-regulated in TPD-affected trees compared to healthy ones. The presence of low levels of $H b T K$ transcripts detected in TPD-affected trees supports the notion of a biological function of TK even in the absence of active meristematic cell division. Of the two tissues examined, increased expression was noticed in bark tissues compared to that of latex cells. Northern blot data showed that the level of HbTK mRNA transcripts accumulated seven-fold higher in the healthy tree than in the TPD-affected one. These results together suggest that up-regulated expression of the $H b T K$ gene in the healthy tree is implicated in active cell division and cellular metabolism.

\section{Discussion}

In our present study, we evaluated the potential of the RAPD method to detect vari ation at the DNA level among Hevea clones. The RAPD assay performs well in terms of number of bands, product yield, and clarity of the profiles. Alterations in RAPD "finger- prints" produced by a random decamer primer set under optimized conditions were seen in one of two ways: there was a gain or loss of a band. In some patterns, changes of a single amplification product appeared; in others, more complicated patterns of gains and losses of bands were observed. RAPD patterns generated by various primers were different among the clones evaluated. It is interesting to note that in this investigation, a distinct polymorphic band was detected with OPA-17 primer, and its nucleotide sequence showed a significant homology to the putative plant $T K$ gene. It has been recognized that RAPD fingerprinting is an effective tool for detection of DNA variation in the nuclear genome because there are a large number of unique nucleotide sequences available for primer binding in the

1 GACCGCTTGT agtcatggag gtttgattga tgaagcttgg gattattct catcaatgaa

61 aagagattat ggaatccagc ccagagggca acactatgca gcaatggtcg atctttagg 121 tcgtgctggc aggttacaag aggcttatga gtttgtactg gaggcacctt gccaggaaca

181 ctcagttgta tggggtgctt tgcttggggc ttgtaggatt catggagaca tggacctggt 241 aattgtgca gctaagaagt actttgaatt ggatccagaa aacgctggaa aatatgtggt

301 cttgtctaat acatatgccg catttgggtt ctgggatgat gttgcaaagg ttaggagtat

361 gatgagagat tcaggaatat tgaaggaacc tgcttatagc aggattggaa gttcaaggag

421 aagtccactg cttcctatgg gtgataaatc tcatagaaaa tctgaggaga tatgtaggac

481 aattatcaaa atgatgcgca ttttaagaga tgctggctat gttcctgata taagtgacca

541 ttaattcatg aagaagactg atatgctta catttagatc caaatctca cctctctat

601 tggctgagct tcccattgca tttctgggct caggttgtta acttgaggta aagctgtttg

661 tgtactaact aaccacataa agtactggat ctgggcttt tttttttta aaaaataca

721 ttaagtaatt accttttat atggttgtat ataattaata attcaggttg agttggtat

781 gttgctatta taccttttg gcttggcaga actctaggtt aggatttctg ttttacct

841 gcaattttcc taggcactat tgcagtatat aacagcgaga ctaatttect gcatatatat

901 cttataggat ttttattct agtttagca atttcagtga gagatggtga tgattraaag

961 cattgttcta tgtagaatct gaaatatatt aaatcttcag caaaattatt atttaaat

1021 tcattttcc tttgtgtaca tttgttatgc agaaatgtag cagttataaa atcaaacagg

1081 gatacaagat atggtttgga ttcaatagtg acacatgatg gggtgaaact gccatgtatg

1141 gcactgccta atttgtcatc atttagacaa aatttggcg ctgatgcata tgagcaggta

1201 tctgaattgc aaacatgat gaactgtatt tttaagaatg atatctaatg tagcctcaaa

1261 aaaagaaag gaatgatatt aatgcatata ttcaatcaag actgaatgtg aactatggaa

1321 agagtcatct agcagttaat attacctgta catttatttg tgtttgagt aaatcattc

1381 tgtgaaagtc aatgtgacta attttgaaa gaatgctacc agaaaatct taatgctgaa

1441 tatatgtgta tattgttctt tctagtttcc tgagtttaca gtgtatacta ggtgatatta

1501 actcatgatg agtacatggt gacagctgga tgtgattggt attgacgaag cacaatttt

1561 tgaagaccta tatgattet gccgcgaagc tgctgatcat gatggaaaa cttaatagt

1621 tgctggtcta gatggtaact attgaggta tatgctcgtt gtcaaaccta ctgatgttat

1681 atatatatag ttttatgctc attacatatt tcttctcctc tggaattct gcttactagt

1741 taatccatcg gttaattgct taaaatcaca ttacattact atcagagctc ctttgatgg

1801 tggattaaat attgttgaca ggaggagttt tggttgtgta cttgatataa ttcctcttgc

1861 tgattcggta actaagttaa ctgcacggtg tgaacttgt ggaaacgtg ctttcttac

1921 cttgagaaag acagaggaga caaggataga acttattggt ggggctgatg tctacatgcc 1981 tgtatgtcga caccactatg tcagtggACA AGCGGTC

Figure 4. Nucleotide sequence of RAPD polymorphic DNA obtained using primer. The primer sequence (upper case letters) is underlined (Accession No. AY130829).

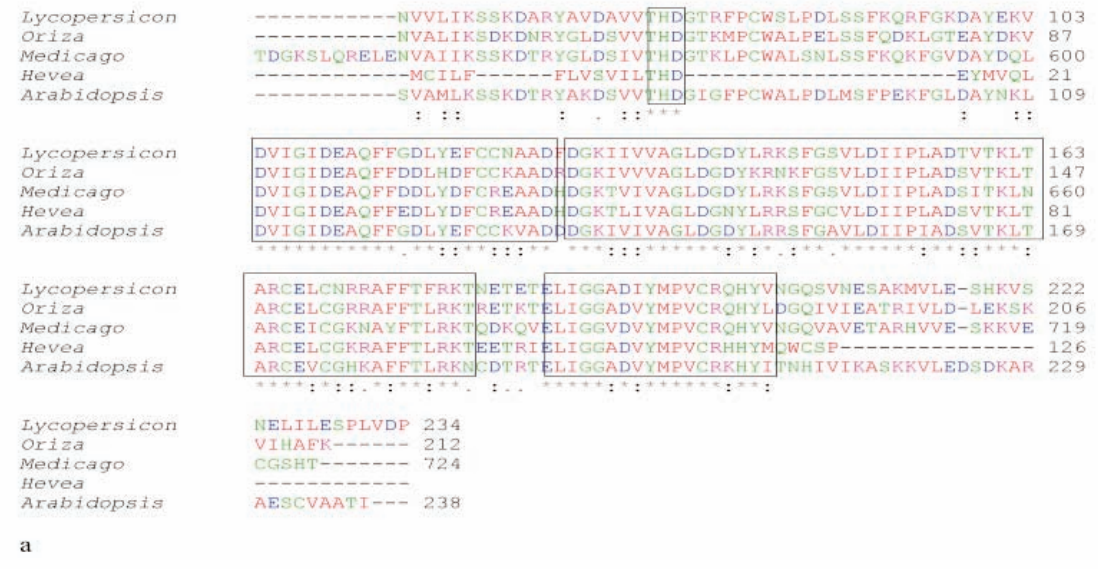

Figure 5. (A) Multiple alignments of the amino acid sequence of HbTK from Medicago, Lycopersicon, Oryza, and Arabidopsis. The alignments were generated using the ClustalW program. ${ }^{19}$ (B) Phylogenetic analysis deduced amino acid sequences of TK genes. The phylogenetic analysis was performed using the TreeView program. 
nuclear genome relative to the organelle genome. ${ }^{4,7,8,22}$ The dendrogram clearly showed that the TPD-tolerant clones clustered together compared to that of the susceptible one. This result suggests that the identified RAPD marker is specific to TPD-tolerant clones.

The identified polymorphic band nucleotide sequence confirms that the cloned DNA fragment was coding for a putative plant TK protein. So far, few TK gene sequences have been reported from the following plant species, viz. Oryza, Medicago, Lycopersicon, and Arabidopsis, but no detailed information is available. A bioinformatics search with TK sequences indicated that the RAPD fragment had significant homology between 1550 bp and 2017 bp. A sequence similarity tree was generated to establish correlation and detection of possible genetic relationships by grouping of Hevea TK with other plant $T K$ genes. The Hevea TK was clustered with Medicago and branched next to Lycopersicon and Oryza and its position within the tree suggests that Hevea TK gene is more similar to other plant species. As the probe hybridized to the Hevea genomic DNA, we putatively concluded that Hevea has a TK homolog in its genome. In addition, multiple hybridization signals suggest that $T K$ represents as one of the members of a small gene family. In order to obtain insight about the TK expression, we studied possible differences in $T K$ gene expression between mature bark tissue and latex cells.

In the Hevea tree, mature bark tissues were tapped (wounded) regularly to harvest latex. Therefore, it is quite possible that the occurrence of DNA damage within the latex-producing cells followed by tapping (wounding) may be one of the causes for the onset of TPD, which leads to cell death (bark dryness) at the tapped site of the rubber tree. It is well characterized that intensive tapping stress results in significant reduction of latex biosynthesis largely mediated via the generation of reactive oxygen species (ROS) and lutoid burst (latex cell damage) within the laticifer cells of TPDaffected trees. ${ }^{23}$ The Northern blot result indicates that down-regulated expression of the $T K$ gene correlates with the lack of meristematic activity in TPD-affected tree bark tissues. ${ }^{24}$ This supports the notion that up-regulated TK expression may be involved in the DNA damage repair mechanism in the healthy tree. An earlier study indicated that TK expression has been found in various tissue types, including mature tissues, in response to DNA damage repair. ${ }^{25}$ Although there are reports on putative TK activity from plants, ${ }^{26}$ purification of the enzyme has not been reported from plants, and in addition it is poorly understood. In plant cells, ROS is the primary cause for DNA damage, which makes a continuous threat to the integrity and viability of the cell even in the absence of external stress. ${ }^{27}$ Therefore, one
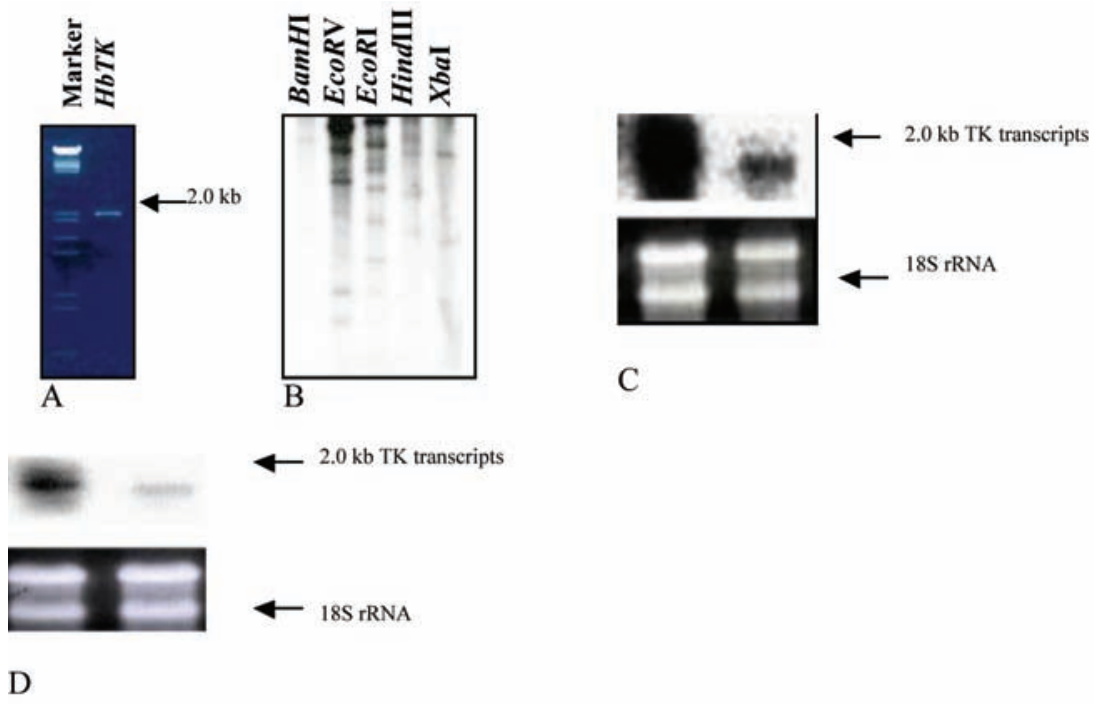

C

Figure 6. (A) PCR-amplified TK gene fragment used for ${ }^{32} \mathrm{P}$ labeling. (B) Southern blot analysis of genomic DNA (10 $\mu$ g) digested with BamHI, EcoRI, EcoRV, HindIII, and $X b a I$ enzymes. Northern blot analysis of $H b T K$ transcripts in mature bark tissues (C) and latex cell (D). Each lane contains $15 \mu \mathrm{g}$ of total RNA. Ribosomal RNA was used to normalize RNA loading.

can hypothesize that increased ROS production owing to tapping in TPD-affected trees may cause DNA damage, which could probably inhibit active cell division at the tapped site of the Hevea tree. These results further support the notion that decreased latex biosynthesis in TPD-affected trees may be because of lack of active nucleotide metabolism.

In conclusion, the RAPD fingerprinting has been successfully used to identify the $H b T K$ gene. Further, decreased expression of the HbTK gene is associated closely with TPD syndrome development in the rubber tree. This is the first report of the cloning and characterization of the TK gene from Hevea. It would be interesting to study the possible involvement of the identified TK gene in various rubber clones affected by TPD, to consider as potential molecular marker for TPD diagnosis.

\section{References}

1. Chrestin H, Gidrol X, Kush A. Towards a latex molecular diagnostic of yield potential and the genetic engineering of the rubber tree. Euphytica 1997;96:77-82.

2. Backhaus RA. Rubber formation in plants mini review. Israel J Bot 1985;34:283-93.

3 . RRII. World production and consumption of natural rubber. Rub Stat Bull 2006;31: 37-8.

4. Venkatachalam P, Priya P, Gireesh T, et al. Molecular cloning and sequencing of a polymorphic band from rubber tree [Hevea brasiliensis (Muell.) Arg.]: the nucleotide sequence revealed partial homology with proline-specific permease gene sequence. Curr Sci 2006;90:1510-5.

5. Chen S, Peng S, Huang G, et al. Association of decreased expression of a Myb transcription factor with the TPD (tapping panel dryness) syndrome in Hevea brasiliensis. Plant Mol Biol 2003; 51:51-8.

6. Williams JGK, Kubelik AR, Livak KJ, et al. DNA polymorphism amplified by arbitrary primers are useful as genetic markers. Nucleic Acids Res 1990;7:6531-5.

7. Das M, Bhattacharya S, Pal A. Generation and characterization of SCARs by cloning and sequencing of RAPD products: A strategy for species-specific marker development in bamboo. Ann Bot 2005;95:835-41.

8. Bhattacharya E, Ranade SA. Molecular distinction amongst varieties of mulberry using RAPD and DAMD profiles. BMC Plant Biol 2001;1:3.

9. Venkatachalam P, Thomas S, Priya P, et al. Identification of DNA polymorphism within the clones of Hevea brasiliensis (Muell.) Arg. using RAPD analysis. Indian J Nat Rubb Res 2002;15:172-181.

10. Venkatachalam P, Priya P, Saraswathyamma C K, et al. Identification, cloning and sequence analysis of a dwarf genomespecific RAPD marker in rubber tree (Hevea brasiliensis Muell. Arg.). Plant Cell Rep 2004;23:327-32.

11. M'Ribu H K, Hilu KW. Detection of interspecific and intraspecific variation in 
Panicum millets through random amplified polymorphic DNA. Theor Appl Genet 1994;88:412-6.

12. Martin G B, Williams JGK, Tanksley SD. Rapid identification of markers linked to a Pseudomonas resistance gene in tomato by using random primers and near-isogenic lines. Proc Natl Acad Sci USA 1991; 88:2336-40.

13. Paran I, Kesseli R, Michelmore R. Identification of RFLP and RAPD markers linked to Downey mildew resistance gene in lettuce using near-isogenic lines. Genome 1991;34:1021-7.

14. Valle PR, Souza MB, Pires EM, et al. Arbitrarily primed PCR fingerprinting of RNA and DNA in Entamoeba histolytica. Rev Inst Med Trop Sao Saulo 2004;42:24953.

15. Dian K, Sangare A, Diopoh JK. Evidence for specific variation of protein pattern during tapping panel dryness condition development in Hevea brasiliensis. Plant Sci 1995;105:207-16.

16. Darussamin A, Suharyanto S, Chaidamsari T. Change in the chemical composition and electrophoretic profile of latex and bark protein related to tapping panel dryness incidence in Hevea brasiliensis. Menara Perkebunan 1995;63: 52-9.

17. Lacrotte R, Gidrol X, Vichitcholchai N, et al. Protein markers of tapping panel dryness. Plant Rech Dev 1995;2:40-5.

18. Sambrook J, Fritsch EF, Maniatis T. Molecular cloning: a laboratory manual, 2nd edn. New York: Cold Spring Harbor Laboratory Press, 1989.

19. Thompson JD, Higgins DG, Gibson TJ. CLUSTAL W: improving the sensitivity of progressive multiple sequence alignment through sequence weighting, positionspecific gap penalties and weight matrix choice. Nucleic Acids Res 1994;22:4673-80.

20. Altschul SF, Madden TL, Schaffer AA, et al. Gapped BLAST and PSI-BLAST: A new generation of protein database search programs. Nucleic Acids Res 1997;25:3389402.

21. Venkatachalam P, Thanseem I, Thulaseedharan A. A rapid and efficient method for isolation of RNA from bark tissues of Hevea brasiliensis. Curr Sci 1999;77:1013.
22. Enan ER. Application of random amplified polymorphic DNA (RAPD) to detect the genotoxic effect of heavy metals. Bio technol Appl Biochem 2006;43:147-54.

23. Chrestin H. Biochemical aspects of bark dryness induced by overstimulation of rubber tree with Ethrel. In: Physiology of Rubber Tree Latex. d'Auzac J, Jacob JL, Chrestin H. (eds). Boca Raton, FL: CRC Press, 1989, pp 341-441.

24. Vinoth T, Premakumari D, Reghu CP, et al. Anatomical and histochemical aspects of bark regeneration in Hevea brasiliensis. Ann Bot 1995;75:421-6.

25. Al-Nabulsi I, Takamiya Y, Voloshin Y, et al. Expression of thymidine kinase is essential to low dose radiation resistance of rat glioma cells. Cancer Res 1994;54:5614-7.

26. Georgieva EI, Lòpez-Rodas G, Hittmair A, et al. Maize embryo germination. Planta 1994;192:118-24.

27. Bray CM, West CE. DNA repair mechanisms in plants: crucial sensors and effectors for the maintenance of genome integrity. New Phytol 2005;168:511-28. 